\title{
Berpikir kritis siswa ditinjau dari gaya kognitif visualizer dan verbalizer dalam menyelesaikan masalah geometri
}

\author{
Widodo Winarso, Widya Yulistiana Dewi ${ }^{1}$
}

\begin{abstract}
Abstrak: Strategi siswa dalam menyelesaikan masalah matematika tentunya tidak lepas dari cara siswa menerima dan mengolah informasi yang disebut sebagai gaya kognitif. Siswa mempunyai gaya kognitif yang berbeda ketika belajar. Ada siswa memiliki gaya kognitif visualizer dan ada juga yang memiliki gaya kognitif verbalizer. Perbedaan gaya kognitif tersebut akan memicu kemampuan berpikir kritis siswa. Penelitian ini dilakukan di Madrasah Tsanawiyah Daru'I Hikam Kota Cirebon dengan menggunakan metode kuantitatif jenis kausalkomparatif. Teknik pengambilan sampel menggunakan cluster random sampling, dengan jumlah sampel sebanyak 45 siswa, yaitu 24 siswa visualizer dan 21 siswa verbalizer. Hasil penelitian menunjukkan bahwa siswa visualizer memperoleh nilai rata-rata sebesar 50,15 sedangkan siswa verbalizer memperoleh nilai rata-rata 40,05. Apabila dilihat dari rata-rata persentase hasil tiap aspek berpikir kritis, siswa visualizer dapat dikategorikan cukup baik, sedangkan siswa verbalizer dapat dikategorikan kurang. Hal ini menunjukan bahwa terdapat perbedaan berpikir kritis antara siswa dengan gaya kognitif visualizer dan siswa dengan gaya kognitif verbalizer dalam menyelesaikan masalah geometri.
\end{abstract}

Kata kunci: Berpikir Kritis; Gaya Kognitif; Pemecahan Masalah; Geometri

\begin{abstract}
Student's strategy in solving mathematics problem cannot be separated from the way students receive and process the information which is called as cognitive style. Students have different cognitive styles as they learn. They tend to have visualizer cognitive style and the others have verbalizer. The different cognitive styles will trigger students' critical thinking skills. This research was conducted in Madrasah Tsanawiyah Daru'l Hikam Cirebon using the quantitative method of a causal-comparative. The sampling technique used cluster random sampling, with a total sample of 45 students, 24 students are visualizer and the remaining is verbalizer. The results showed that the visualizer students obtained an average score of 50.15, while the verbalizer students got 40.05 . Viewing from the average percentage of the results of each aspect of critical thinking, visualizer students can be categorized quite well, while the verbalizer students can be
\end{abstract}

\footnotetext{
${ }^{1}$ IAIN Syekh Nurjati Cirebon, Indonesia, widodoiain@gmail.com
} 
categorized less. This research implies that there are differences in critical thinking between students with visualizer cognitive style and students with verbalizer in solving geometry problems.

Keywords: Critical Thinking; Cognitive Style; Problem-solving; Geometry

\section{A. Pendahuluan}

Pembelajaran matematika merupakan sebuah proses pemberian pengalaman belajar tentang matematika kepada siswa melalui kegiatan terencana yang disiapkan oleh guru. Dalam pembelajaran matematika, guru harus memberikan peluang kepada siswa untuk berusaha dan mencari pengalamannya sendiri terkait objek matematika yang sedang dipelajarinya. Menurut Burton (2012), tujuan belajar matematika adalah mendorong siswa untuk menjadi pemecah masalah (problem solver) berdasarkan proses berpikir yang kritis, logis, dan rasional. Namun, kebanyakan siswa menganggap bahwa pembelajaran matematika merupakan pembelajaran yang sulit karena kebanyakan siswa kurang memiliki minat yang tinggi jika menjumpai soal-soal matematika yang tidak sederhan bahkan cenderung menghindarinya.

Strategi siswa dalam menyelesaikan masalah matematika khususnya pada materi geometri tentunya tidak lepas dari cara siswa menerima dan mengolah informasi yang didapatkan yang disebut sebagai gaya kognitif. Siswa mempunyai gaya yang berbeda dalam memecahkan masalah dan ketika mereka belajar. Siswa akan memilih cara yang disukai dalam memproses dan mengorganisasi informasi sebagai respon terhadap lingkungannya (Sari \& Budiarto, 2016).

Menurut Uno (2006) gaya kognitif merupakan suatu cara yang berbeda untuk melihat, mengenal, dan mengorganisasi informasi. Namun, kebanyakan guru kurang mengetahui tipe gaya kognitif dari masingmasing siswanya. Oleh karena itu, seorang guru dituntut untuk dapat mengetahui tipe gaya kognitif siswanya. Menurut Keefe (1979), pengelompokan gaya kognitif didasarkan atas empat dimensi, yaitu: 1) Perceptual modality preference, merupakan gaya kognitif yang berkaitan dengan kebiasaan dan kesukaan seseorang dalam menggunakan alat 
indranya khususnya kemampuan melihat gerakan secara visual atau spasial, pemahaman auditory atau verbal. 2) Field dependent field independent, merupakan gaya kognitif yang dimiliki seseorang dalam berinteraksi dengan lingkungannya. 3) Scanning, merupakan gambaran kecenderungan seseorang dalam menitikberatkan perhatiannya pada suatu informasi. 4) Strong and weakness automatization, merupakan gambaran kapasitas seseorang untuk menampilkan tugas (task) secara berulang-ulang.

Informasi yang disajikan dalam matematika dapat berupa simbol verbal dan simbol visual. Penerimaan informasi berupa simbol verbal dan simbol visual ini termasuk pada perceptual modality preference, informasi tersebut dapat diterima oleh siswa bisa berbeda tergantung pada gaya kognitifnya. Menurut McEwan dan Reynolds (2007), gaya kognitif yang berkaitan dengan kebiasaan seseorang menggunakan alat inderanya dibagi menjadi dua kelompok, yaitu visualizer dan verbalizer. Seseorang dengan gaya kognitif visualizer cenderung lebih mudah untuk menerima, memproses, menyimpan, dan menggunakan informasi dalam bentuk gambar maupun grafik (Hegarty \& Kozhevnikov, 1999). Sedangkan seseorang dengan gaya kognitif verbalizer cenderung lebih mudah untuk menerima, memproses, menyimpan, dan menggunakan informasi dalam bentuk pembahasaan teks atau tulisan.

Hal senada juga diungkapkan Klein (2003), bahwa siswa yang bergaya kognitif visualizer, memiliki kecenderungan dalam menerima informasi dalam pembelajaran yang sifatnya visual (misalnya diagram, gambar, dan grafik)sedangkan yang menyukai informasi lisan yang dapat dibaca atau didengarkan termasuk kedalam siswa yang bergaya kognitif verbalizer. Perbedaan gaya kognitif ini tentunya berpengaruh pada strategi yang digunakan dalam menyelesaikan masalah matematika. Maka siswa dengan gaya kognitif yang berbeda tentunya memiliki strategi pemecahan masalah yang berbeda sehingga perbedaan itu akan memicu perbedaan kemampuan berpikir kritis siswa (Sari \& Budiarto, 2016).

Kemampuan berpikir merupakan dasar dalam suatu proses pembelajaran (Heong, Yunos, Hassan, Othman, \& Kiong, 2011). Berpikir kritis memungkinkan siswa untuk menganalisis pikirannya dalam menentukan pilihan dan menarik kesimpulan dengan cerdas. Kemampuan berpikir kritis merupakan bagian dari kemampuan berpikir tingkat tinggi 
(Krulik, 1996). Apabila siswa diberi kesempatan untuk menggunakan pemikiran dalam tingkatan yang lebih tinggi di setiap tingkat kelas, pada akhirnya mereka terbiasa membedakan antara kebenaran dan kebohongan, penampilan dan kenyataan, fakta dan opini, pengetahuan dan keyakinan. Kemampuan berpikir kritis merupakan cara berpikir reflektif dan beralasan yang difokuskan pada pengambilan keputusan untuk memecahkan masalah (Ennis, 1985). Dengan demikian, proses mental ini akan memunculkan kemampuan berpikir kritis siswa untuk dapat menguasai matematika secara mendalam.

Hasil penelitian Jacob (2012) menjelaskan bahwa pembelajaran matematika dalam keterampilan berpikir kritis, jika didorong dengan benar dapat menghasilkan perbaikan dalam pencapaian matematis. Menurut Kim, Sharma, Land dan Furlong (2013) bahwa melalui penerapan modul pembelajaran aktif, tingkat kritis siswa rata-rata turun dalam kategori "berkembang", namun nilai siswa pada laporan individual menunjukkan peningkatan yang signifikan secara statistik. Valindra (2014) menambahkan bahwa keterampilan disposisi dan inferensi telah menunjukkan kontribusi signifikan terhadap kemampuan berpikir kritis matematis.

Berdasarkan wawancara dengan guru mata pelajaran matematika di Madrasah Tsanawiyah Daru'l Hikam, kemampuan berpikir kritis siswa dalam pembelajaran matematika masih kurang, karena dilihat dari sebagian siswa ketika diberi latihan soal yang berbeda sedikit dari contoh soal yang sudah dijelaskan siswa mengalami kesulitan. Sebagaimana hasil studi kasus yang dilakukan oleh peneliti di kelas, bahwa siswa mengalami kesulitan dalam mengerjakan soal geometri yang berkaitan dengan kehidupan sehari-hari, dalam hal ini siswa masih kurang berpikir secara lebih mendalam. Selain itu, siswa juga kurang teliti dalam menjawab soal. Siswa hanya menghafal rumus saja tanpa memahaminya, sehingga siswa kurang mengatur strategi dalam menjawab soal.

Kemampuan berpikir kritis siswa sangat perlu dikembangkan untuk mendukung keberhasilan dalam belajar matematika khususnya pada penyelesaian masalah geometri. Berpikir kritis dapat membantu siswa dalam meningkatkan pemahaman materi yang dipelajari dengan mengevaluasi secara kritis argumen pada buku, diskusi kelompok, tugas dalam menyelesaikan permasalahan, dan termasuk juga argumentasi guru 
dalam kegiatan pembelajaran. Seorang guru perlu memikirkan langkahlangkah yang tepat untuk membuat proses pembelajaran matematika yang memberikan kesempatan bagi siswa untuk dapat mengembangkan kemampuan berpikir kritisnya.

Guru dapat melatih kemampuan berpikir kritis dengan menghadapkan siswa pada masalah-masalah yang sifatnya menantang, seperti masalah geometri. Masalah yang menantang tersebut akan memberikan kesempatan kepada siswa untuk menggunakan segala kemampuan yang dimiliki termasuk kemampuan berpikir tingkat tinggi yaitu berpikir kritis. Bailin, Case, Coombs, dan Daniels (1999) mendefinisikan kompetensi dalam berpikir kritis memiliki yang dibutuhkan sumber daya intelektual untuk menyelesaikan tugas-tugas tertentu secara memadai dan secara bersama dengan kebiasaan untuk menerapkannya secara tepat.

Gambaran tahapan berpikir kritis dapat dilihat melalui langkahlangkah siswa dalam menyelesaikan masalah geometri. Langkah-langkah dalam menjawab permasalahan siswa berbeda-beda antara yang bergaya kognitif visualizer dengan bergaya kognitif verbalizer sehingga diperlukan kemampuan seorang guru dalam memahami gambaran berpikir kritis siswa. Perlakuan tersebut diperlukan agar guru dapat melihat kesesuaian pembuatan rancangan pembelajaran dengan gaya kognitif siswa.

Berdasarkan uraian di atas, maka yang menjadi rumusan masalah dalam penelitian ini, yaitu: 1) Bagaimana sebaran gaya kognitif siswa? 2) Bagaimana keterampilan berpikir kritis siswa ditinjau dari gaya kognitif visualizer dan verbalizer dalam menyelesaikan masalah geometri? Dan 3) Adakah perbedaan berpikir kritis antara siswa bergaya kognitif visualizer dengan siswa yang bergaya kognitif verbalizer dalam menyelesaikan masalah geometri?

\section{B. Metode Penelitian}

Penelitian ini menggunakan metode kuantitatif jenis kausalkomparatif (Mertens, 2014). Fokus dalam penelitian ini mengenai berpikir kritis siswa ditinjau dari gaya kognitif visualizer dan verbalizer dalam menyelesaikan masalah geometri. Penelitian ini dilakukan di Madrasah Tsanawiyah Daru'I Hikam Kota Cirebon tahun ajar 2016/2017. 
Teknik pengambilan sampel dalam penelitian ini menggunakan Cluster Random Sampling, yaitu peneliti mengambil sampel kelompok secara acak, dalam hal ini kelompok tersebut dianggap sebagai rombongan belajar (rombel). Peneliti menggunakan cara undian untuk menentukan sampel (Kothari, 2004) sedangkan untuk mendapatkan target sampel penelitian, peneliti memberikan angket kesuluruh siswa kelas VIIIB dan VIIIC dari kelas VIII yang ada. Hal tersebut dilakukan untuk mengidentifikasi gaya kognitif siswa, verbalizer atau visualizer. Kemudian didapat sampel dalam penelitian ini adalahkelas VIII B yang terdiri dari 14 siswa visualizer dan 11 siswa verbalizersedangkan untuk kelas VIII C terdiri dari 10 siswa visualizer dan 10 siswa verbalizer.

Instrumen pengumpulan data yang digunakan dalam penelitian ini adalah angket dan tes (Cohen, Manion\& Morrison, 2013). Angket yang digunakan dalam penelitian ini dikembangkan oleh penulis. Adapun dalam proses pengembangnya mengadopsi konsep gaya kognitif (Thomas\& McKay, 2010) dan pengukuran skala sikap(Boone\& Boone, 2012). Angket atau kuesioner ini berupa kuesioner tertutup, digunakan untuk mengklasifikasikan gaya kognitif yang dimiliki dari masing-masing siswa. Kuesioner terdiri dari 24 item pernyataan yang terbagi menjadi 2 bagian yaitu 12 pernyataan untuk gaya kognitif visualizer dan 12 pernyataan untuk gaya kognitif verbalizer. Masing-masing pernyataan memiliki 4 alternatif jawaban yaitu, Sangat Setuju (SS), Setuju (S), Tidak Setuju (TS), Sangat Tidak Setuju (STS) dengan skala likert.

Tabel 1. Kisi-kisi Instrumen Angket

\begin{tabular}{|c|c|c|c|c|}
\hline \multirow{2}{*}{ Gaya Kognitif } & \multirow{2}{*}{ Indikator } & \multicolumn{3}{|c|}{ Item Pertanyaan } \\
\hline & & $(+)$ & $(-)$ & Jumlah \\
\hline \multirow[t]{5}{*}{$\begin{array}{l}\text { Gaya Kognitif } \\
\text { Visualizer }\end{array}$} & $\begin{array}{l}\text { Kemampuan } \\
\text { memahami sesuatu } \\
\text { dalam bentuk gambar } \\
\text { atau grafik }\end{array}$ & 1,5 & 22 & 3 \\
\hline & $\begin{array}{l}\text { Kemampuan mengingat } \\
\text { sesuatu secara visual }\end{array}$ & 18,21 & 13 & 3 \\
\hline & Berpikir secara visual & 7,15 & - & 2 \\
\hline & $\begin{array}{l}\text { Rapi dan teratur } \\
\text { terhadap aktivitas } \\
\text { visual }\end{array}$ & 3 & - & 1 \\
\hline & $\begin{array}{l}\text { Teliti dan singkat dalam } \\
\text { menjawab pertanyaan }\end{array}$ & 9,19 & 20 & 3 \\
\hline
\end{tabular}




\begin{tabular}{|l|l|c|c|c|}
\hline \multirow{2}{*}{ Gaya Kognitif } & \multicolumn{1}{|c|}{ Indikator } & \multicolumn{3}{c|}{ Item Pertanyaan } \\
\cline { 2 - 5 } $\begin{array}{l}\text { Gaya Kognitif } \\
\text { Verbalizer }\end{array}$ & $\begin{array}{l}\text { Kemampuan } \\
\text { memahami sesuatu } \\
\text { secara verbal }\end{array}$ & 11,23 & 2 & 3 \\
\cline { 2 - 5 } & $\begin{array}{l}\text { Kemampuan mengingat } \\
\text { sesuatu secara verbal }\end{array}$ & 8 & 4 & 2 \\
\cline { 2 - 5 } & \begin{tabular}{l} 
Kemampuan berbicara \\
\cline { 2 - 5 }
\end{tabular} & $6,12,17$ & 16 & 4 \\
\hline & $\begin{array}{l}\text { Kemampuan berpikir } \\
\text { dalam mengolah kata }\end{array}$ & 14 & 10 & 2 \\
\cline { 2 - 5 } & $\begin{array}{l}\text { Menjawab pertanyaan } \\
\text { dengan jawaban rinci }\end{array}$ & 24 & - & 1 \\
\hline \multicolumn{2}{|c|}{ Jumlah } & & 24 \\
\hline
\end{tabular}

Tes yang digunakan dalam penelitian ini berbentuk essay (uraian) yang dikembangkan oleh peneliti. Adapun pengembangan tes mengadopsi konsep capaian belajar geometri di sekolah menengah (Van de Walle, Karp \& Williams, 2007) dan pengembangan tes uraian (Ennis, \& Weir, 1985; Detlefsen, 2013). Jumlah tes uraian yang digunakan sebanyak 8 item yang digunakan untuk mengukur keterampilan berpikir kritis siswa.

Tabel 2. Kisi-kisi Instrumen Tes

\begin{tabular}{|c|l|c|}
\hline \multicolumn{1}{|c|}{ Tes } & \multicolumn{1}{|c|}{ Indikator } & Nomor Soal \\
\hline Berpikir Kritis & $\begin{array}{l}\text { Memberikan penjelasan sederhana cara } \\
\text { menemukan rumus luas permukaan kubus }\end{array}$ & 3 \\
\cline { 2 - 3 } & $\begin{array}{l}\text { Membangun keterampilan dasar dalam } \\
\text { menentukan kebenaran sifat-sifat balok }\end{array}$ & 1 \\
\cline { 2 - 3 } & $\begin{array}{l}\text { Menyimpulkan hasil perhitungan volume } \\
\text { kubus pada gambar dengan cara } \\
\text { membandingkan }\end{array}$ & 6,7 \\
\cline { 2 - 3 } & $\begin{array}{l}\text { Memberikan penjelasan lanjut dalam } \\
\text { menghitung volume kubus dan balok }\end{array}$ & $2,5,8$ \\
\cline { 2 - 3 } & $\begin{array}{l}\text { Mengatur strategi dan taktik dalam } \\
\text { menghitung volume kubus serta luas } \\
\text { permukaan kubus dan balok }\end{array}$ & $\mathbf{8}$ \\
\hline
\end{tabular}

Hipotesis dalam penelitian ini merupakan hipotesis komparasional. Uji hipotesis yang digunakan adalah uji t (Independen Samples T Test). 
Namun sebelum melakukan pengujian hipotesis, maka diperlukan pengujian prasyarat yang meliputi uji normalitas dan uji homogenitas.Jika data berpikir kritis siswa tersebut berdistribusi normal maka pengujian dilanjutkan dengan uji homogenitas dan uji hipotesis yaitu uji t untuk dua sampel independen. Sebaliknya jika data berpikir kritis siswa yang diperoleh tidak berdistribusi normal maka pengujian dilanjutkan dengan uji homogenitas dan uji hipotesis yaitu uji mann whitney $U$.

\section{Temuan dan Pembahasan}

Hasil penelitian setelah dilakukan studi lapangan, berdasarkan penyebaran angket gaya kognitif di kelas VIIIBMadrasah Tsanawiyah Daru'I Hikam Kota Cirebon, diperoleh siswa cenderung memiliki gaya kognitif visualizer sebanyak $56 \%$ (14 orang) dan siswa cenderung memiliki gaya kognitif verbalizer sebanyak $44 \%$ (11 orang). Hal ini menunjukkan bahwa sebagian besar siswa di kelas VIIIB cenderung memiliki gaya kognitif visualizer. Di kelas VIIIC, siswa cenderung memiliki gaya kognitif visualizer sebanyak $50 \%$ (10 orang) dan siswa cenderung memiliki gaya kognitif verbalizer sebanyak 50\% (10 Orang). Hal ini menunjukkan bahwa jumlah siswa di kelas VIIIC yang memiliki gaya kognitif visualizer sama banyak dengan siswa yang memiliki gaya kognitif verbalizer.

Sebaran gaya kognitif menunjukan tingkat keberagaman gaya kognitif siswa. Hal ini dijadikan sebagai prediktor dalam penelitian ini karenagaya kognitif diakui sebagai dimensi psikologis yang penting sebagai pembeda cara individu dalam memperoleh dan memproses informasi (Ausburn \& Ausburn, 1978). Selain itu, gaya kognitif telah diakui berbeda dengan kemampuan kognitif, kecerdasan, kepribadian, dan gaya belajar (Kozhevnikov, 2007; Riding, 1997). Gaya kognitif juga merupakan prediktor kinerja akademis yang baik jika dibandingkan dengan telaah pada kecerdasan individu (Sternberg \& Zhang, 2014).

Hal tesebut akan berdampak pada kemampuan berpikir siswa dalam menyelesaikan masalah matematika. Penyelesaian masalah matematika, khususnya pada materi geometri dapat dilakukan dengan berpikir sederhana maupun berpikir kritis. Menurut Ennis (1985), bahwa berpikir kritis merupakan pemikiran reflektif dan masuk akal yang berfokus pada penentuan apa yang harus dilakukan atau dipercaya. Kemampuan berpikir kritis mencakup hal-hal seperti menerapkan informasi yang tersedia ke situasi baru, menganalisis penyebab atau motif untuk situasi, dan mengevaluasi pendapat tentang subjek tertentu. Sedangkan Mcpeck (2016) mendefinisikan berpikir kritis sebagai keterampilan dan disposisi 
untuk secara tepat menggunakan skeptisisme reflektif. Lipman (2003) mengklaim bahwa berpikir kritis adalah pemikiran yang memungkinkan untuk menilai, didasarkan pada kriteria, mengkoreksi, serta kritis terhadap konten.

Keberagaman gaya kognitif tersebut menjadi fokus pembahasan terkait dengan berpikir kritis siswa dalam menyelesaikan masalah geometri. Adapun data penelitian yang terkait dengan capaian berpikir kritis siswa adalah sebagai berikut.

Tabel 3. Hasil Statistik Deskriptif

\begin{tabular}{|l|c|c|c|c|c|c|}
\hline & N & Minimum & Maximum & Mean & $\begin{array}{c}\text { Std. } \\
\text { Deviation }\end{array}$ & Variance \\
\hline $\begin{array}{l}\text { Berpikir Kritis Siswa } \\
\text { Verbalizer }\end{array}$ & 24 & 35 & 73 & 50,15 & 11,595 & 134,445 \\
\hline Valid N (listwise) & 24 & & & & & \\
\hline $\begin{array}{l}\text { Berpikir Kritis Siswa } \\
\text { Verbalizer }\end{array}$ & 21 & 22 & 63 & 40,05 & 13,577 & 184,323 \\
\hline Valid N (listwise) & 21 & & & & & \\
\hline
\end{tabular}

Berdasarkan hasil analisis statistik deskriptif, diperoleh nilai rata-rata berpikir kritis 50,15 untuk siswa dengan gaya kognitif visualizer dalam menyelesaikan masalah geometrisedangkan siswa dengan gaya kognitif verbalizermemperoleh nilai rata-rata 40,05. Hal ini berarti bahwa siswa dengan gaya kognitif visualizer cenderung lebih baik daripada siswa dengan gaya kognitif verbalizer dalam menyelesaikan masalah geometri.

Perbedaan gaya kognitif siswa ini memiliki efek terhadap keterampilan berpikir kritis. Berpikir kritis melibatkan penalaran logis dan kemampuan memisahkan fakta dari opini, memisahkan informasi secara kritis dengan pembuktian sebelum informasi tersebut diterima atau ditolak. Dengan kata lain bahwa berpikir kritis membuat siswa menganalisis, mempertanyakan isu, memberikan gagasan, memberikan solusi dari masalah yang dipecahkan sehingga siswa dapat mengambil keputusan cerdas saat menghadapi tantangan dalam belajar (Rfaner, 2006). Menurut Fahim \& Pezeshki (2012), bahwa Kemampuan berpikir kritis melibatkan penalaran dan aktif pertimbangan apa yang diterima dari pada penerimaan gagasan begitu saja. Pendapat lain merefleksikan bahwa berpikir kritis sebagai pemikiran reflektif yang dapat disesuikan dengan konsep pemikirannya, seperti pemikiran tingkat tinggi, pemecahan masalah, dan metakognisi (Ennis, 1987; 1989; McPeck, 1990). 
Pembelajaran matematika sebaiknya dapat melibatkan siswa dalam teknik belajar aktif, dalam konteks keterampilan interpersonal dapat meningkatkan berpikir kritis siswa (Burbach, Matkin \& Fritz, 2004) sehingga diperlukanpembelajaran kooperatif yang dapat membangun keterampilan berpikir kritis tersebut. Pada konteks yang sama, berdasarkan data siswa pada tes berpikir kritis dalam menyelesaikan masalah geometri, diketahui bahwa siswa dengan gaya kognitif visualizer unggul dalam tiga aspek, yaitu memberikan penjelasan sederhana, membangun keterampilan dasar, serta mengatur strategi dan taktik. Sedangkan siswa dengan gaya kognitif verbalizer unggul pada dua aspek berpikir kritis dalam menyelesaikan masalah geometri, yaitu aspek menyimpulkan dan memberikan penjelasan lanjut (Grafik 1).

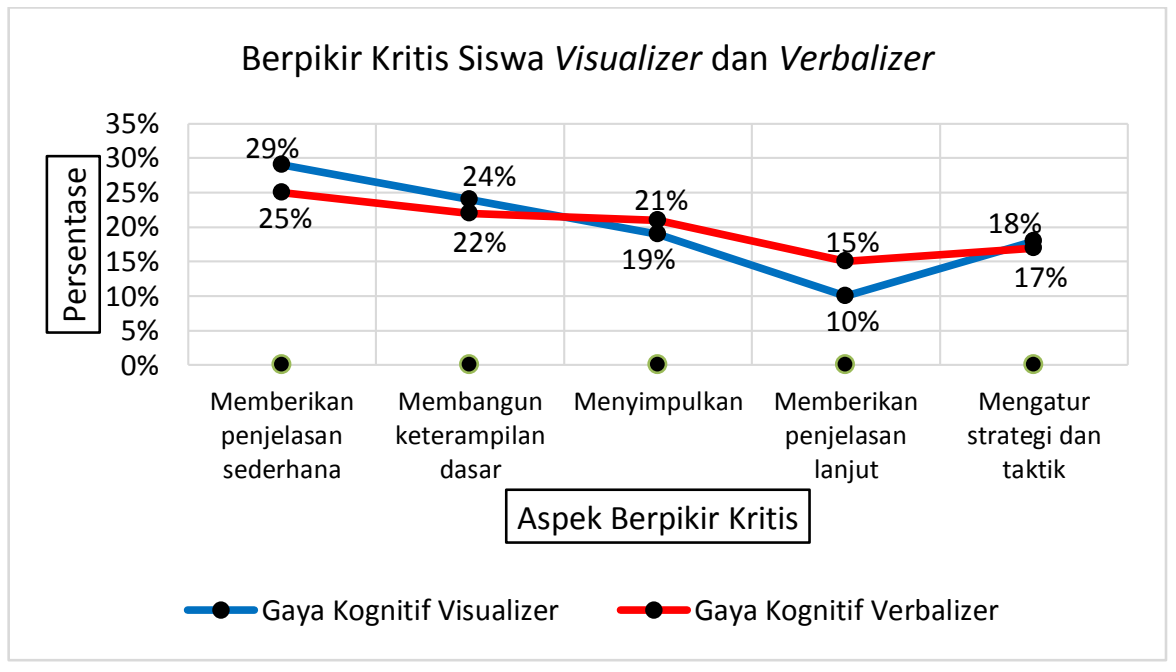

Grafik 1.Perbandingan Berpikir Kritis Siswa

Pada aspek pertama, yaitu aspek "kemampuan memberikan penjelasan sederhana" lebih unggul siswa yang bergaya kognitif visualizer jika dibandingkan dengan siswa gaya kognitif verbalizer dengan besaran selisih presentasenya adalah $4 \%$. Pada aspek yang kedua, yaitu aspek "membangun keterampilan dasar" lebih unggul siswa yang bergaya kognitif visualizer jika dibandingkan dengan siswa gaya kognitif verbalizer dengan besaran selisih presentasenya adalah $2 \%$. Hal tersebut berarti bahwasiswa dengan gaya kognitif visualizer mampu memberikan jawaban dengan penjelasan yang sederhana (singkat) namun jelas dalam menyelesaikan masalah geometri, serta mampu membangun keterampilan dasar geometri. 
Pada aspek yang ketiga dan keempat memiliki makna kecenderungan lain. Siswa gaya kognitif verbalizer jika dibandingkan dengan siswa gaya visualizer lebih unggul pada kemampuan menyimpulkan dengan besaran selisih presentasenya adalah $2 \%$, dan kemampuan memberikan penjelasan lanjut terkait pemecahan masalah geometri dengan selisih besaran presentasenya adalah $5 \%$. Pada aspek yang kelima, yaitu aspek "kemampuan mengatur strategi dan taktik," siswa gaya kognitif visualizer lebih unggul $1 \%$ capaiannya, jika dibandingkan dengan siswa gaya kognitif verbalizer.

Analisis berikutnya dilakukan pengujian hipotesis. Namun sebelum dilakukanya pengujian, maka di perlukanya persyaratan uji hipotesis. Hal tersebut digunakan untuk mengetahui apakah analisis data dapat dilanjut atau tidak. Pertama, uji normalitas digunakan untuk mengetahui apakah populasi data yang diperoleh melalui tes berpikir kritis siswa dalam menyelesaikan masalah geometri berdistribusi normal atau tidak. Pengujian mengunakan Shapiro-Wilk. Adapun persyaratan uji hipotesis (uji normalitas) adalah sebagai berikut.

Tabel 4. Uji Normalitas

\begin{tabular}{|l|r|r|r|r|r|r|}
\hline & \multicolumn{3}{|c|}{ Kolmogorov-Smirnov $^{\text {a }}$} & \multicolumn{3}{|c|}{ Shapiro-Wilk } \\
\cline { 2 - 6 } & Statistic & Df & \multicolumn{1}{|c|}{ Sig. } & Statistic & df & \multicolumn{1}{c|}{ Sig. } \\
\hline $\begin{array}{l}\text { Berpikir } \\
\text { Kritis }\end{array}$ &, 068 & 45 &, $200^{*}$ &, 978 & 45 &, $\mathbf{5 2 6}$ \\
\hline
\end{tabular}

Berdasarkan Tabel 4, diketahui bahwa dari data yang digabungkan antara siswa dengan gaya kognitif visualizer dan verbalizer diperoleh nilai signifikansi (sig.) pada kolom Shapiro-Wilksebesar 0,526 karena nilai signifikansi (sig.) yang dihasilkan pada kolom Shapiro-Wilk lebih besar dari nilai $\alpha$ yang dipilih, yaitu $\alpha=0,05$ maka data dinyatakan normal. Dengan demikian, dapat disimpulkan bahwa pada taraf kepercayaan 95\%, data berpikir kritis siswa dengan gaya kognitif visualizer dan verbalizerdalam menyelesaikan masalah geometri berdistribusi normal.

Kedua, uji homogenitas digunakan untuk mengetahui apakah populasi data yang diperoleh melalui tes berpikir kritis siswa dalam menyelesaikan masalah geometri tersebut memiliki varian populasi data sama atau tidak. 
Tabel 5. Uji Homogenitas

\begin{tabular}{|r|r|r|r|}
\hline \multicolumn{5}{|l|}{ Berpikir Kritis } \\
\hline Levene Statistic & df1 & df2 & Sig. \\
\hline 1,944 & 1 & 43 &, $\mathbf{1 7 0}$ \\
\hline
\end{tabular}

Berdasarkan Tabel 5, diketahui bahwa diperoleh nilai $P$-value yang ditunjukkan pada kolom signifikansi (sig.) sebesar 0,170. Nilai tersebut lebih besar daripada nilaiayang dipilih, yaitu $\alpha=0,05$ karena nilai $P$ value $>\alpha$ maka $\mathrm{H}_{0}$ diterima. Dengan demikian, dapat disimpulkan bahwa pada taraf kepercayaan $95 \%$ varians data berpikir kritis siswa dengan gaya kognitif visualizer dan verbalizer dalam menyelesaikan masalah geometri adalah berdistribusi homogen.

Setelah melakukan uji prayarat, maka dilakukan pengujian hipotesis. Dimana pengujian hipotesis mengunakan Independent Sampel T-Test. didapat hasil data penelitian sebagai berikut.

Tabel 6. Hasil Independen Samples T Test

\begin{tabular}{|c|c|c|c|c|}
\hline & \multicolumn{2}{|c|}{ Berpikir Kritis } \\
\hline & & & $\begin{array}{l}\text { Equal variances } \\
\text { assumed }\end{array}$ & $\begin{array}{l}\text { Equal } \\
\text { variances } \\
\text { not assumed }\end{array}$ \\
\hline \multirow{2}{*}{$\begin{array}{l}\text { Levene's test } \\
\text { for equality } \\
\text { of variances }\end{array}$} & \multicolumn{2}{|l|}{$\mathrm{F}$} & 1,944 & \\
\hline & \multicolumn{2}{|l|}{ Sig. } & 170 & \\
\hline \multirow{8}{*}{$\begin{array}{l}\text { t-test for } \\
\text { equality of } \\
\text { variances }\end{array}$} & \multicolumn{2}{|l|}{$\mathrm{F}$} & 1,944 & \\
\hline & \multicolumn{2}{|l|}{ Sig. } & , 170 & \\
\hline & \multicolumn{2}{|l|}{$\mathrm{T}$} & 2,692 & 2,663 \\
\hline & \multicolumn{2}{|l|}{ Df } & 43 & 39,636 \\
\hline & \multicolumn{2}{|l|}{ Sig. (2-tailed) } & , 010 & ,011 \\
\hline & \multicolumn{2}{|l|}{ Mean difference } & 10,098 & 10,098 \\
\hline & \multirow{2}{*}{$\begin{array}{l}\text { 95\% Confidence } \\
\text { Interval of the } \\
\text { Difference }\end{array}$} & Lower & 2,532 & 2,432 \\
\hline & & Upper & 17,664 & 17,764 \\
\hline
\end{tabular}

Berdasarkan tabel di atas, dengan melakukan dua macam pengujian didapat sebagai berikut: Pertama, uji Levene's Test forEquality of Variancesyakni untuk menguji data homogen atau tidak. Kedua, Uji T-test for Equality of Means yakni untuk menguji data apakah memiliki perbedaan rata-rata atau tidak. 
Pada hasil uji Levene's Test for Equality of Variances diperoleh nilai Pvalue yang ditunjukkan olehbaris Sig. pada kolom equal variances assumed sebesar 0,170 sehingga dinyatakan varians kedua data homogen karena nilainya lebih besar dari $(\alpha=0,05)$. Pada uji $T$-testfor Equality of Means, nilai yang berada pada kolom $t$ merupakan $t_{\text {hitung }}$ yang diperoleh dari hasil perhitungan.Padakolom equal variances assumed, nilai $t$ menunjukkan tentang siswa pada tes berpikir kritis dalam menyelesaikan masalah geometri, yaitu sebesar 2,692. Pada baris df dihasilkan nilai 43, nilai tersebut merupakan derajat kebebasan pada tes yang dilakukan. Pada baris Sig. (2-tailed) dihasilkan nilai P-value (signifikansi) pada tes berpikir kritis siswa dalam menyelesaikan masalah geometri sebesar 0,010.Baris Mean Difference menunjukkan perbedaan nilai rata-rata antara siswagaya kognitif visualizer dan siswa gaya kognitif verbalizer dalam menyelesaikan masalah geometri.

Telah diketahui sebelumnya bahwa nilai rata-rata berpikir kritis siswa dengan gaya kognitif visualizer dalam menyelesaikan masalah geometri sebesar 50,15 dan siswa dengan gaya kognitif verbalizer dalam sebesar 40,05, sehingga diperoleh perbedaan rata-ratanya sebesar 10,098. Pengujian hipotesis T-test for Equality of Meansmenggunakan taraf kepercayaan $95 \%$ sehingga a yang digunakan sebesar 0,05 . Untuk mengetahui nilai $t_{\text {tabel }}$ dengan $\alpha=0,05$ dan $d k=43$ digunakan bantuan Microsoft Excel $(=\operatorname{TINV}(0,05 ; 43))$ sehingga diperoleh nilai $t_{\text {tabel }}=2,016$ atau $-2,016$.

Dengan demikian, diperoleh nilai $t_{\text {hitung }}>t_{\text {tabel }}=2,692>2,016$, dan nilai Sig. (2-tailed) $<\alpha=0,010<0,05$. Maka keputusannya $H_{0}$ ditolak. Artinya pada taraf kepercayaan $95 \%$ dapat disimpulkan bahwa terdapat perbedaan kemampuan pemecahan masalah geometri antara siswa yang bergaya kognitif visualizer dengan siswa bergaya kognitif verbalizer.

Hasil Perbedaan kemampuan pemecahan masalah geometri tersebut dapat dideskripsikan sebagai berikut:

Pertama, siswa dengan gaya Kognitif visualizer dapat menyebutkan beberapa hal penting dalam membedakan bagian yang relevan dan yang tidak relevan dari suatu permasalahan yang diberikan (Kozhevnikov, Kosslyn \& Shephard, 2005). Namun, masih ada ketidak sesuaian bagi subjek visualizer dalam menerjemahkan informasi dalam tes pemecahan dan penulisan keterangan yang diketahuinya. Subjek visualizer dalam mengumpulkan informasi cenderung mengklasifikasikan informasi dengan kriteria tertentu.Lebih lanjut, subjek visualizer lebih tertarik menyelesaikan permasalahan yang disertai gambar. Kondisi tersebut, sejalan dengan Mendelson (2004) yang mengatakan bahwa subjek 
visualizer tertarik pada informasi dalam bentuk gambar. Berdasarkan penjelasan yang telah dipaparkan, subjek visualizer memahami masalah dengan membedakan informasi yang relevan dan tidak relevan. Mendelson \& Thorson (2004)yang menunjukkan bahwa subjek visualizer dalam menggeneralisasi masalah cenderung menggunakan simbol huruf awal dari kata objek pada soal yang diberikan.

Kedua, siswa bergaya kognitif verbalizer menyebutkan semua hal penting dalam membedakan bagian yang relevan dan yang tidak relevan dari suatu permasalahan yang diberikan. Subjek verbalizer dalam mengumpulkan informasi cenderung mengurutkan sesuai urutan yang diketahui pada soal. Lebih lanjut subjek verbalizer lebih tertarik menyelesaikan permasalahan yang banyak menggunakan kata-kata. kondisi tersebut, sejalan dengan pendapat Mendelson (2004) yang mengatakan bahwa subjek verbalizer tertarik pada informasi dalam bentuk kata-kata. Diperkuat lagi dengan pendapat Mendelson \& Thorson (2004) yang menyatakan bahwa subjek verbalizer dalam menggeneralisasi masalah dengan penggunaan simbol yang cenderung konsisten.

\section{Simpulan}

Berdasarkan hasil analisis dan penelitian mengenai studi komparatif terhadap berpikir kritis siswa ditinjau dari gaya kognitif visualizer dan verbalizer dalam menyelesaikan masalah geometri, dapat disimpulkan bahwa:

1. Sebaran gaya kognitif di kelas VIII B Madrasah Tsanawiyah Daru'I Hikam Kota Cirebon cenderung memiliki gaya kognitif visualizer. Sedangkan, sebaran gaya kognitif di kelas VIIIC sama banyak antara visualizer dan verbalizer.

2. Siswa dengan gaya kognitif visualizer memperoleh nilai rata-rata tes berpikir kritis dalam menyelesaikan masalah geometri sebesar 50,15. Berdasarkan perolehan rata-rata persentase hasil dari tiap aspek berpikir kritis siswa dengan gaya kognitif visualizer dapat dikategorikan cukup baik.

3. Siswa dengan gaya kognitif verbalizer memperoleh nilai rata-rata tes berpikir kritis dalam menyelesaikan masalah geometri sebesar 40,05. Berdasarkan perolehan rata-rata persentase hasil dari tiap aspek berpikir kritis siswa dengan gaya kognitif verbalizer dapat dikategorikan kurang baik. 
4. Terdapat perbedaan nilai rata-rata kemampuan berpikir kritis siswa dengan gaya kognitif visualizer dan siswa dengan gaya kognitif verbalizer dalam menyelesaikan masalah geometri.

Hasil penelitian ini mendorong guru mengetahui tipe gaya kognitif yang dimiliki oleh siswa guna untuk menunjang proses pembelajaran matematika. Guru mengunakan media yang variatif, sehingga seluruh siswa memiliki porsi yang berimbang dalam menyerap materi ajar walaupun memiliki gaya kognitif yang berbeda. Penelitian selanjutnya, hendaknya mempertimbangkan materi yang lebih luas lagi agar dapat menggali lebih dalam kemampuan berpikir kritis siswa dalam menyelesaikan masalah geometri.

\section{Daftar Pustaka}

Ausburn, L. J., \& Ausburn, F. B. (1978). Cognitive styles: Some information and implications for instructional design. Educational Technology Research and Development, 4(26), 337-354.

Bailin, S., Case, R., Coombs, J. R., \& Daniels, L. B. (1999).Conceptualizing critical thinking. Journal of curriculum studies, 31(3), 285-302.

Baxter, P., \& Jack, S. (2008). Qualitative case study methodology: Study design and implementation for novice researchers. The qualitative report, 13(4), 544-559.

Boone, H. N., \& Boone, D. A. (2012).Analyzing likert data. Journal of extension, 50(2), 1-5.

Burbach, M. E., Matkin, G. S., \& Fritz, S. M. (2004).Teaching critical thinking in an introductory leadership course utilizing active learning strategies: A confirmatory study. College Student Journal, 38(3), 482-494.

Burton, L. (Ed.). (2012). Learning mathematics: From hierarchies to networks. London: Routledge.

Cohen, L., Manion, L., \& Morrison, K. (2013). Research methods in education. London: Routledge.

Detlefsen, M. (2013). Hilbert's program: an essay on mathematical instrumentalism (Vol. 182). New York: Springer Science \& Business Media.

Ennis, R. H. (1987). A taxonomy of critical thinking dispositions and abilities. In J. B. Baron \& R. J. Sternberg (Eds.), Series of books in psychology. Teaching thinking skills: Theory and practice (pp.9-26). New York: W H Freeman/Times Books/ Henry Holt \& Co. 
Ennis, R.H. (1985). Goals for a critical thinking curriculum. In Costa, A (Ed), Developing minds: A resource book for teaching thinking (pp.6876). Alexandria, VA: Association for Supervision and Curriculum Development, Alexandria, Virginia.

Ennis, R. H. (1989). Critical thinking and subject specificity: Clarification and needed research. Educational researcher, 18(3), 4-10.

Ennis, R. H., \& Weir, E. E. (1985). The Ennis-Weir critical thinking essay test: An instrument for teaching and testing. Pacific Grove, CA: Midwest Publications.

Fahim, M., \& Pezeshki, M. (2012). Manipulating critical thinking skills in test taking. International Journal of Education, 4(1), 153-160.

Hegarty, M., \& Kozhevnikov, M. (1999).Types of visual-spatial representations and mathematical problem solving. Journal of educational psychology, 91(4), 684.

Heong, Y. M., Yunos, J. M., Hassan, R. B., Othman, W. B., Kiong, T. T. (2011). The perception of the level of higher order thinking skills among technical education students. International Conference on Social Science and Humanity journal. Faculty of Technical Education, Universiti Tun Hussein Onn Malaysia, 5(2), 281-285.

Jacob, S. M. (2012). Mathematical achievement and critical thinking skills in asynchronous discussion forums. Procedia-Social and Behavioral Sciences, 31, 800-804.

Keefe, J. W. (1979). Learning Style: An overwiev in NASSP student learning style: Diagnosis and Prescibing Program. Reston, VA: National Association of Secondary School Principles.

Kendall, P. C., \& Hollon, S. D. (Eds.). (2013). Cognitive-behavioral interventions: Theory, research, and procedures (Vol. 21). London: Academic Press.

Kim, K., Sharma, P., Land, S. M., \& Furlong, K. P. (2013). Effects of active learning on enhancing student critical thinking in an undergraduate general science course. Innovative Higher Education, 38(3), 223-235.

Klein, P. D. (2003). Rethinking the multiplicity of cognitive resources and curricular representations: Alternatives to'learning styles' and'multiple intelligences'. Journal of curriculum studies, 35(1), 45-81.

Kothari, C. R. (2004). Research methodology: Methods and techniques. New Delhi: New Age International.

Kozhevnikov, M. (2007). Cognitive styles in the context of modern psychology: toward an integrated framework of cognitive style. Psychological Bulletin, 133(3), 464.

Kozhevnikov, M., Kosslyn, S., \& Shephard, J. (2005). Spatial versus object visualizers: A new characterization of visual cognitive style. Memory \& cognition, 33(4), 710-726. 
Krulik, S. (1996). The new sourcebook for teaching reasoning and problem solving in junior and senior high school. Boston: Allyn \& Bacon.

Lipman, M. (2003). Thinking in education. New York: Cambridge University Press.

McEwan, R. C., \& Reynolds, S. (2007). Verbalizers and visualizers: Cognitive styles that are less than equal. Fanshawe College: Disability Services, Counselling \& Student Life. Fanshawe College, Canada.

McPeck, J. E. (1990). Critical thinking and subject specificity: A reply to Ennis. Educational Researcher, 19(4), 10-12.

McPeck, J. E. (2016). Critical thinking and education. London: Routledge.

Mendelson, A. L. (2004). For whom is a picture worth a thousand words? Effects of the visualizing cognitive style and attention on processing of news photos. Journal of Visual Literacy, 24(1), 1-22.

Mendelson, A. L., \& Thorson, E. (2004). How verbalizers and visualizers process the newspaper environment. Journal of Communication, 54(3), 474-491.

Mertens, D. M. (2014). Research and evaluation in education and psychology: Integrating diversity with quantitative, qualitative, and mixed methods. USA: Sage publications.

Rfaner, S. (2006). Enhancing thinking skills in the classroom. Humanity \& Social Sciences Journal, 1(1), 28-36.

Riding, R. J. (1997). On the nature of cognitive style. Educational psychology, 17(1-2), 29-49.

Sari, E. M. J., \& Budiarto, M. T. (2016). Profil berpikir kritis siswa SMP dalam menyelesaikan masalah geometri ditinjau dari gaya kognitif visualizer dan verbalizer. Jurnal Ilmiah Pendidikan Matematika, 2(5), 39-47.

Sternberg, R. J., \& Zhang, L. F. (Eds.). (2014). Perspectives on thinking, learning, and cognitive styles. London:Routledge.

Thomas, P. R., \& McKay, J. B. (2010). Cognitive styles and instructional design in university learning. Learning and Individual Differences, 20(3), 197-202.

Uno, H. B. 2006. Orientasi baru dalam psikologi pembelajaran. Jakarta: Bumi Aksara.

Valindra, D. (2014). The contribution of disposition and inference skills to critical thinking mathematics ability of students at senior high school Jakarta. In Ratu Ilma (Eds).The Second South East Asia Design/ Development Research (SEA-DR) International Conference, April 2627,2014, Unsri, Palembang, April 26th-27th,2014, Palembang.

Van de Walle, J. A., Karp, K. S., \& Williams, J. M. B. (2007). Elementary and middle school mathematics. Teaching development. Boston: Pearson. 